\title{
Modification of the State Budget and Tax Policy for E-commerce in the Context of the Global Corona Crisis
}

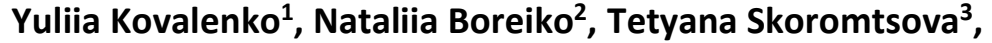 \\ IuliiaPanura ${ }^{4}$ and Oleksandr Boreiko ${ }^{5}$
}

\author{
${ }^{1}$ Department of Financial Markets, University of the State Fiscal Service of Ukraine, Irpin, Ukraine \\ ${ }^{2}$ Institute of Fiscal Policy, University of the State Fiscal Service of Ukraine, Irpin, Ukraine \\ ${ }^{3,4}$ Department of Tax Policy, University of the State Fiscal Service of Ukraine, Irpin, Ukraine \\ ${ }^{5}$ University of the State Fiscal Service of Ukraine, Irpin, Ukraine
}

Correspondence should be addressed to: Yuliia Kovalenko; kovalenko0202@ukr.net

Received date: 11 December 2020; Accepted date: 1 February 2021; Published date: 22 March 2021

Academic Editor: Anatolii Pavlenchyk

Copyright (C) 2021. Yuliia Kovalenko, Nataliia Boreiko, Tetyana Skoromtsova, luliiaPanura and Oleksandr Boreiko. Distributed under Creative Commons Attribution 4.0 International CC-BY 4.0

\begin{abstract}
The article reveals topical issues of improving the state budget and tax policy for ecommerce entities in the global economic crisis caused by the spread of corona virus infection COVID-19. The purpose of the article is to study the current state of e-commerce in Ukraine and identify possible ways of modifying the state budget and tax policy for ecommerce in the situation of deepening corona crisis. The article is based on general scientific methods of cognition: abstract-logical, dialectical and system analysis, induction and deduction, analogy and extrapolation, as well as logical generalization. E-commerce is a promising activity that has been showing steady growth for many years. The ability to do business online allows many businesses to adapt to new business conditions, including quarantine restrictions imposed by the spread of corona virus COVID-19. E-commerce is a type of economic activity, which is developing, and at the same time it is a reliable source of budget, despite the crisis. However, since businesses in this area faced the problem of the economic crisis, they need state support. The potential of e-commerce is significant. It allows its subjects to reorient its activity depending on the needs of the business environment. This feature should be taken into account when developing measures to support this area and providing conditions for its sustainable growth. The proposed measures will increase the number of online stores, the turnover from operations in this area, the sales of goods via the Internet, the number of taxpayers and tax revenues to the state budget.
\end{abstract}

Keywords: e-commerce, COVID-19, business entities, taxation.

Cite this Article as: Yuliia Kovalenko, Nataliia Boreiko, Tetyana Skoromtsova, IuliiaPanura and Oleksandr Boreiko (2021)," Modification of the State Budget and Tax Policy for E-commerce in the Context of the Global Corona Crisis ", Journal of Financial Studies \& Research, Vol. 2021 (2021), Article ID 104815,

DOI: $10.5171 / 2021.104815$ 


\section{Introduction}

Considering the extraterritorial nature of ecommerce operations, as well as the global scale of corona crisis, many business participants have been negatively affected by the pandemic as well as the quarantine. In most cases, the risks are associated with the lack of payments under the agreements, customers' refusal to purchase planned goods (works, services) and the difficulty of supplying physical goods.

According to the Global Innovation Index 2019, in recent years, Ukraine is on the list of countries whose per capita income is below the average, and in 2019, it held the second place among the 26 countries included in the sample by this criterion (out of 130 countries covered in the research). After all, according to experts of the International Monetary Fund, countries with low per capita incomes and developing countries are to be placed in the highest risk zone during the current crisis.

Recently, there has been a steady growth of the e-commerce market in Ukraine and in the world. However, the outbreak of the COVID-19 corona virus pandemic has caused a global economic crisis. It has also affected e-commerce activities.

For most countries of the world, the problem of choosing the mechanism of ecommerce taxation to ensure the filling of the state budget is relevant. Taking into account the fact that each country has different tax regimes and tax rates, entrepreneurs have the opportunity to produce, exchange and place their goods and services based on their values in different parts of the world (usually in more attractive tax jurisdictions) (ParisAlmansa, 2019). Sometimes, this is contrary to the interests of the state where the entrepreneur is registered as a taxpayer and, as a result, that causes tax competition.

Therefore, in the current situation, support for e-commerce at the state level is crucial. In the absence of effective measures, supporting the domestic segment of e- commerce and the IT industry may increase the shadowing of this area and the outflow of highly qualified professionals abroad. This will negatively affect the filling of the state budget.

This work will focus on highlighting the current state of e-commerce in Ukraine and identifying the possible ways of improving the taxation of the subjects of this activity in the situation of corona crisis.

\section{The Main Part}

Today, e-commerce taxation issues are being discussed by statesmen, politicians and scientists, trying to properly address such issues, as the World Wide Web is perceived as a kind of interstate and international information environment. Thanks to this network, completely new markets have been formed and are dynamically developing, forming an independent segment of the world economy (Yurchuk, 2000). The latest includes e-commerce, so the authors believe that improving the mechanism of tax regulation of e-commerce with maximum consideration of its specific features is an important scientific task.

The formation of the idea of e-commerce, its subjects, ways and methods of its implementation was influenced by the works of famous scientists such as Winston (1997), Summer and Duncan (1999), Schoder and Straub (1999), Tanzi (2001), Germanov and Shaytura (2013), Dick, Kokoreva and Shaytura (2013), as well as Shaytura, Kozhayev, Ordov, Antonenkova and Zhenova (2017). Problems of ecommerce are tackled in the scientific publications of Yurchuk (2000), Koren (2007, 2011), Tymchenko, Melnyk, Tarangul and others (2008), Nellen (2008), Papis-Almansa (2019), Redih (2020) and others. However, the issue of improving the taxation of e-commerce and supporting its subjects in the context of the corona crisis requires additional studies. This is due to the fact that doing business on the Internet and excessive tax burden in most countries, including Ukraine, encourages its subjects to apply schemes to minimize tax liabilities, 
as well as to transfer economic activity to countries with a favorable tax climate.

At the beginning of 2020, before the outbreak of the pandemic, e-commerce in Ukraine accounted about $4 \%$ of the total retail market. According to the results of 2019 in Ukraine, the volume of the ecommerce market amounted more than 97 billion UAH, of which the sold physical goods and services were worth more than 76 billion UAH, which is $17 \%$ more than it was in 2018. According to experts, in 2020, volumes of purchasing and selling goods on the Internet are expected to increase up to over 87 billion UAH (or 15\%). It is worth noting that globally, e-commerce market in 2019 amounted more than 3.3 trillion US dollars, which is 531 billion US dollars more than it was in 2018. According to market analysts, in 2020, sales are expected to exceed to 3.8 trillion USA dollars (Redih, 2020).

Of all the e-commerce sectors in Ukraine, the most common type is B2C - Businessto-Consumer, which is represented mainly by online stores and marketplaces, where goods are sold to the final consumer. The level of trust in making purchases on the Internet has strengthened and every one third of Internet users buys goods online (Ishchenko, 2020). With the outbreak of the pandemic and the introduction of quarantine measures, a significant number of consumers switched to buying goods (works, services) online. Therefore, ecommerce, unlike other areas of economic activity, was able to achieve balance and survive during a crisis, but with some losses.

The government has taken a number of urgent measures to support domestic businesses, including a partial easing of fiscal pressures (through the introduction of tax breaks and tax exemptions for the supply of goods where it is necessary to implement pandemic measures, a moratorium on tax audits, etc.) (Boreyko, Kovalenko and Krasnova, 2017). However, taking into account that it is difficult to estimate the magnitude of businesses and state losses due to the corona crisis, experts emphasize the need for government support for businesses at least for the coming years.

According to the analysis of the works of Tymchenko, Melnyk and Tarangul and others (2008), the introduction of new taxes as an additional source of filling the budget, in particular taxes in the field of ecommerce, is quite justified.

However, this can lead to the manifestation of not only stimulating but also disincentive function of taxes (Koren, 2011). An effective push for the development of e-commerce at the initial stage may be the introduction of a moratorium on the introduction of new taxes for several years (following the example of the United States), as well as the non-interference of the state in the face of relevant regulatory authorities. However, it does not preclude the introduction of special tax regimes or tax benefits for businesses in the field of commerce to stimulate activity and increase tax revenues to the state budget.

The most acceptable direction for the implementation of transformations in the field of e-commerce taxation may be making some amendments to the legislation of Ukraine, taking into account the foreign experience and the recommendations of international organizations. This conclusion coincides with the position of the Organization for Economic Co-operation and Development, which in its document "ECommerce: Framework for Taxation" (OECD, 1998), determines that the basic principles of taxation applied to traditional trade should be guided by e-commerce taxation. Of course, these principles should be taken into account when carrying out the improvement of its taxation. However, ecommerce is a specific activity, so it requires the development of special measures with maximum consideration of its features.

\section{Research Methodology}

In the process of the research, it was established that the modern system of taxation of e-commerce entities in Ukraine is based on the application of generally established norms and rules of taxation (Fig. 1). 


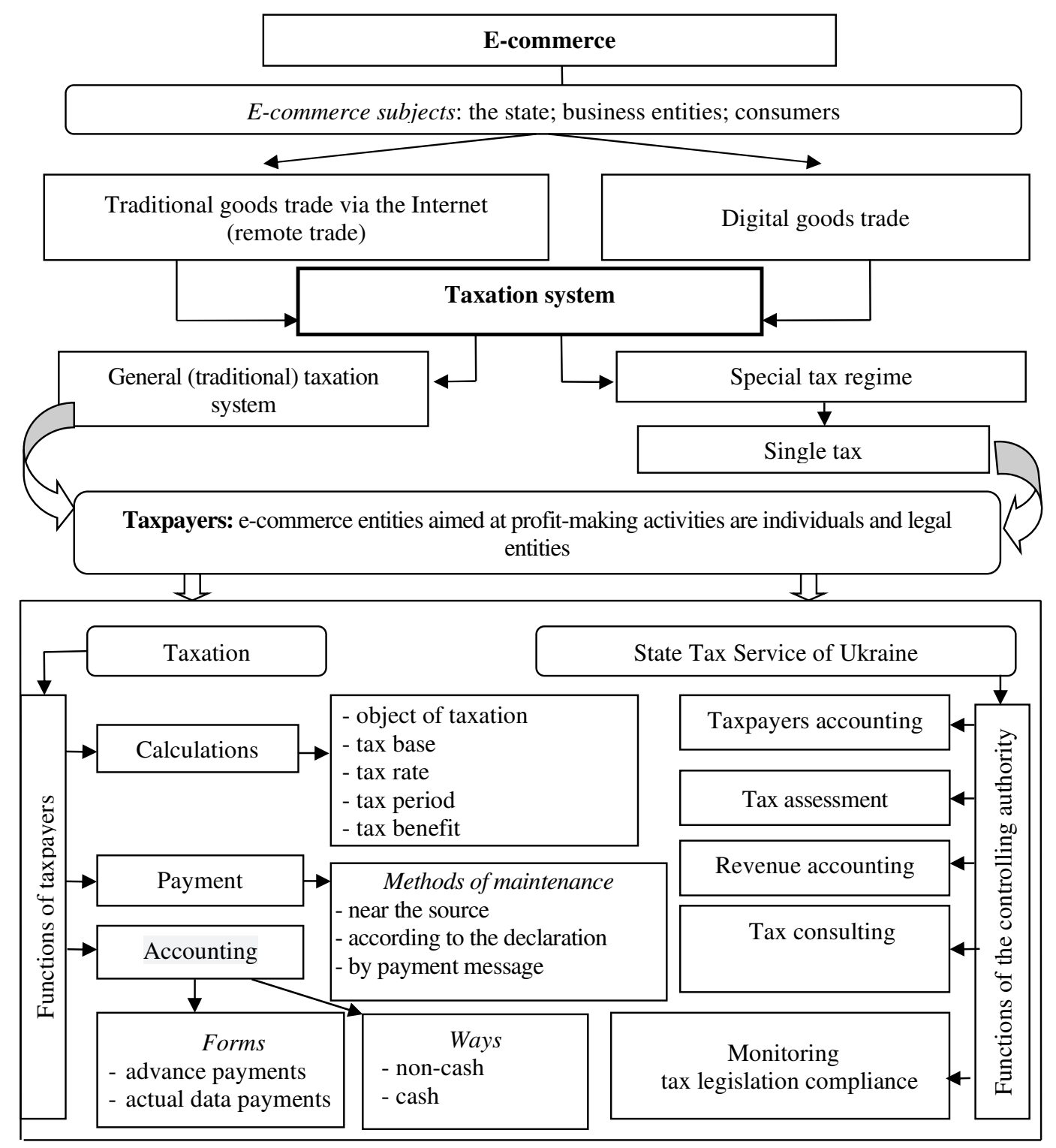

Fig. 1: The main elements of taxation of the system of e-commerce entities (source: Boreyko, Kovalenko. and Krasnova (2017)

However, the mechanism of taxation of ecommerce entities does not take into account a number of specific features of this type of activity, which encourages businesses to hide a significant amount of financial resources and reduce the tax base. In modern tax legislation, there are not enough effective methods of tax control, which allow identifying e-commerce entities that underestimate the amount of actual income (Boreyko, Kovalenko and Krasnova, 2017). Papis-Almansa (2019) notes that, in practice, it is difficult to ensure an effective control of e-commerce, because most transactions of purchase (sale) are carried out on the Internet, and 
each batch of goods is almost impossible to verify.

In order to alleviate the negative impact of the pandemic crisis, as well as to find ways to expand the tax base and de-shadow business in the field of e-commerce, it is advisable to consider tax breaks (cancellation or deferral of VAT payments until the end of 2020), preferential lending and state support for the financing of the IT industry (in particular, through government procurement for the development and provision of digital services). An effective means of support may be the introduction of tax holidays for newly created e-commerce entities (for 2 years), which will stimulate new work place creation and will help reduce the unemployment rate in the country. As a result, in the future it will have a positive impact on filling the state budget.

It will be essential to consider measures to carefully intensify activities in the field of ecommerce and its taxation.

A reduction of VAT rate on certain activities in the field of IT technologies, which are currently the most popular (for example, the development of software for online services (online education, on-line medicine, on-line employment, etc.)) may be a significant reduction in the impact of the crisis on e-commerce entities. State support may be provided in the form of an increasing share of advance payments (up to $50 \%$ ) for e-commerce entities that are involved in ensuring the supply of goods (works, services) for state needs for the period of overcoming the consequences of the pandemic.

The development and implementation of an online system of early bankruptcy prevention (such system is successfully used in the European Union) can be a resisting way of the shadowing of ecommerce and other areas of activity.

In the future, the best option for ecommerce taxation in Ukraine could be using alternative tax systems. The essence of this approach is to form a methodology for calculating tax base, namely the introduction of fixed indicators that will allow tax authorities to control ecommerce entities and tax revenues, and therefore, activities will lead to filling the state budget (Koren, 2011).

Alternative taxes in the world are applied to those activities where there is a significant turnover of funds that are difficult to control and tax. In particular, in such countries as Turkey, Tunisia and Morocco, alternative taxes are used instead of VAT on small businesses, and in Pakistan, they are used instead of excise tax (Azarov, 2011). The application of alternative taxes prevents the relocation of significant turnovers to the shadow segment of the economy. Taking into account the specific features of ecommerce and the tendency of its subjects to conceal or underestimate the tax base, and other violations of tax legislation, this experience can be really relevant for Ukraine.

One of the alternative forms is the income tax. This tax is applied to the taxation, not of the actually received income, but of the estimated (conditional) one. That means, when using this approach, the average possible (or projected) income is taxed. Using such tax provides the assignment of each payer to a particular type of activity for whom the average rate of return is set separately. Considering Ukrainian realities, such approach is promising.

The creation of a special regime may lead to the fact that the provided tax benefits will be used as a mechanism of minimizing tax liabilities. However, the Internet itself is a driving force for the economies in many countries; therefore, the provision of such benefits can be seen as a preference from the state for rapidly developing ecommerce.

On the other hand, the introduction of new taxes for the taxation of e-commerce entities will be irrational and burdensome, as reforming the current tax system in Ukraine is aimed at reducing the number of taxes and fees. However, domestic tax legislation contains the concept of a single tax, which allows non essential changes 
and additions to the Tax Code of Ukraine. This will take into account the specific features of the research area, namely the development of indicators of basic profitability and fixed physical indicators of its entities. Considering the virtual nature of e-commerce, the application of this approach will verify the correctness of the calculation of the tax base of business entities and minimize their opportunities in terms of the understatement of the tax base. As a result, this will attract more participants, having been taxed.

In addition, it will contribute to: 1) expanding the tax base, in particular, by reducing tax evasion in this area; 2) reduction of administrative costs in the implementation of control and verification measures; 3) taxation fairness. After all, such approach does not create incentives for the understatement of income by economic entities but promotes the taxation of income, which in other conditions may be escaped from taxation (Boreyko, Kovalenko and Krasnova, 2017).

State tax policy and practical aspects of ecommerce taxation should exist as symbiotic areas and should be considered analogically. After all, improving the mechanism of e-commerce taxation is impossible without a proper understanding of the necessary methodological framework, and the last one may lead to the impossibility of implementing innovations in practice.

\section{Results of the Research}

Nowadays, the Tax Code of Ukraine does not define the physical fixed indicators of business entities in the field of e-commerce and the amount of basic income they have. But the peculiarities of the domestic tax system will allow creating an effective tool for the modern taxation of such entities on the basis of the above mentioned approach. This approach has two important advantages: 1) Minimal costs of tax control; 2) The impossibility of distorting the tax base by the taxpayer.

It is useful to adapt the studied approach to Ukrainian realities by introducing a special tax regime for e-commerce entities on the basis of a simplified taxation system, namely, assigning these entities to a separate (additional) group of single taxpayers with annual income with transition period: 2021 - 10 million UAH; 2022 - 15 million UAH; and 2023 - UAH 20 million UAH. On the one hand, the introduction of an additional group of taxpayers in the Tax Code of Ukraine will ensure the legalization and reduction of the shadow segment of e-commerce, and, on the other hand, it will not require significant financial costs to improve taxation.

According to the proposed approach, the subject of taxation is a business entity that receives income from business activities on the Internet. In fact, the object of taxation is the established income received by a legal entity or individual from the sale of goods (works, services) through using information and communication systems. And at the same time, the tax base is the amount of the established income.

Therefore, a special tax regime is proposed to apply, with the following variables for payers of the additional group of the single tax, in particular, business entities in the field of ecommerce. The single tax base (TB) is proposed to be calculated as the difference between the amount of the basic income, expenses and social tax benefit by the formula (1):

$$
\mathrm{TB}=\mathrm{I}_{\mathrm{B}}-\mathrm{Ex}-\mathrm{B}_{\text {soc }},
$$

$\mathrm{I}_{\mathrm{B}}$-basic income adjusted for inflation per taxable entity; Ex-expenses; $\mathrm{B}_{\mathrm{soc}}$-social tax benefit.

Ів can be calculated by the following formula (2):

$$
\mathrm{IB}_{\mathrm{B}}=\frac{\mathrm{I}}{1+\mathrm{I}_{\mathrm{Ac}}-\mathrm{I}_{\mathrm{B}}} \text {, }
$$

Yuliia Kovalenko, Nataliia Boreiko, Tetyana Skoromtsova, IuliiaPanura and Oleksandr Boreiko (2021), Journal of Financial Studies \& Research, DOI: 10.5171/2021.104815 
Where I is the estimated fixed income, that is an income in value terms per one taxable entity; $I_{A c}$ is the actual inflation index; $I_{B}$ is an index of inflation laid down in the budget.

Reducing basic income, when actual inflation exceeds budget forecast, will allow the entrepreneur to compensate for these losses by reducing tax base. That is, using formula (2) is aimed at supporting the entrepreneur, not the budget, but, paradoxically, in the future, it will strengthen the country's economy.

Expenses (Ex) are calculated by applying two coefficients $\mathrm{K}_{\mathrm{I}}$ and $\mathrm{K}_{\mathrm{e} \text {-com to the amount }}$ of received basic income $\mathrm{I}_{\mathrm{B}}$ by formula (3):

$$
\mathrm{Ex}=\mathrm{I}_{\mathrm{B}} \times \mathrm{K}_{\mathrm{I}} \times \mathrm{K}_{\mathrm{e}-\text { com, }}
$$

$\mathrm{K}_{\mathrm{I}}$ is reducing the basic income ratio $\left(\mathrm{K}_{\mathrm{I}}=\right.$ $0,8)$;

$\mathrm{K}_{\mathrm{e}-\mathrm{com}}$ is a corrective preferential coefficient of the basic income of e-commerce, which is determined by the peculiarities of an economic activity of e-commerce product groups and takes into account traditional goods trade (works, services) (remote trade) and digital goods trade (works, services).

$$
\mathrm{B}_{\mathrm{soc}}=\sum_{t h}^{n} \mathrm{~S}_{t h} \times n_{t h},
$$

$\mathrm{S}_{t h}$ is the minimum salary for $n_{t h}$ months.

A transition period is proposed to apply for the single tax rates for a separate group of taxpayers, in particular, business entities in the field of e-commerce: 2021 - 20\%; 2022 $18 \% ; 2023-15 \%$. On the one hand, the proposed reduction of the single tax rate to $15 \%$ of the potential income of e-commerce entities will reduce the level of tax evasion and reduce the shadow segment of the economy; on the other hand, it will ensure the economic efficiency of this tax. After all, excessive tax pressure encourages businesses to look for gaps in tax legislation and use various schemes of tax evasion, reduce or even stop the business activity.

The single social contribution is calculated based on the same tax base as the single tax for single tax rates for a separate group of taxpayers.

Based on research by Russian scientists Frolova (2009) and Koren (2007; 2011), it can be argued that the analysis of ecommerce indicators is quite difficult
The social tax benefit (STB) is calculated as following: the monthly social tax benefit is $100 \%$ of the minimum salary on January 1 st of the reporting period (on January 1st, 2020 , it was $4,723 \mathrm{UAH}$ ). If the minimum wage does not change during the year, the $\mathrm{STB}=4723 \times 12 \mathrm{UAH}$, and if it changes, the social tax benefit will be calculated by formula (4):

because there are problems with collecting data on the enterprises' activities, their income, quantity and type of products, etc. This is often due to the fact that ecommerce is a relatively new activity and is used by most companies as an additional way to market or promote products. The latest ones do not carry out separate accounting of transactions occurring on the Internet, which makes it difficult to obtain reliable data.

In general, the application of the proposed measures to support e-commerce in the context of the economic crisis will contribute to the further development of this area, increase the number of online stores in Ukraine, turnover from operations in this area, and sales of goods via the Internet, increase the number of taxpayers and tax revenues to the state budget, as well as reduce the amount of concealment of transactions' income. 


\section{Conclusion}

During recent years, a steady growth of the e-commerce market in Ukraine and in the world can be seen. However, the outbreak of the COVID-19 corona virus pandemic has caused a global economic crisis. It has also affected e-commerce businesses.

In the context of the above mentioned topic, the formation of an effective system of e-commerce taxation, which would take into account the specific features of the economic activity on the Internet, is one of the urgent issues closely related to increasing revenues to the state budget and Ukrainian development. The developed measures should be aimed at filling the state budget, because the socio-economic situation of the country's citizens depends on the timely tax payments. The introduction of tax holidays, preferential crediting of the industry, increasing the share of advance payments (up to 50\%) for e-commerce entities involved in the supply of goods (works, services) for the state, government orders for the supply of goods (works, services) by entities e-commerce, in particular the IT industry for the period of overcoming the effects of the pandemic, will be a stimulus for work place creation, and thus contribute to reducing the unemployment rate in Ukraine, which in turn will have a positive impact on filling the state budget.

In the case of the stabilization of the crisis related to the COVID-19 pandemic, it is worth considering the possibility of introducing an alternative tax system for ecommerce entities, which, according to the analysis of the scientific literature, is successfully applied to those activities where the significant turnover is difficult to control and tax.

\section{References}

- Azarov, M. Ya. (ed) (2011) State budget and budget strategy in terms of economic reforms.Vol. 1: Stabilization of public finances in the context of the reform strategy, DNNU Academy of Financial Management, Kiev.
- Boreyko, N., Kovalenko, Yu. and Krasnova, T. (2017) Taxation of electronic commerce in Ukraine, Alerta, Kiev.

- Cornell Universit, The global innovation index 2019. INSEAD, WIPO. 78. [Online], [Retrieved October 25, 2020], https://www.wipo.int/edocs/pubdocs/ en/wipo_pub_gii_2019-chapter1.pdf.

- Frolova, L. V. (2009) Taxation of electronic trade, Saratov State Technical University, Saratov.

- International Monetary Fund. [Online], [Retrieved October 28, 2020], https://www.imf.org/en/News/Articles /2020/04/07/sp040920-SMs2020-

Curtain-Raiser.

- Ishchenko, A. (2020), 'Shopping on the Internet: the most popular goods among Ukrainians have become known',Today, Jan. 20. [Online], [Retrieved October 12, 2020],https://www.segodnya.ua/en/uk raine/pokupki-v-internete-nazvanysamye-populyarnye-u-ukraincevtovary-1389792.html.

- Koren, A. V. (2007) Taxation of ecommerce entities on the basis of a single tax on imputed income, Vladivostok State University of Economics and Service, Vladivostok.

- Koren, A. (2011), Taxation of ecommerce entities: problems and prospects,VGUES Publishing House, Vladivostok.

- Kovalenko, Yu. M. (2013),'Standards within the Code of Good Practice for financial activities', Actual Problems of Economics, 148(10), 8-14.

- Nellen, A. (2008), 'E-Commerce Taxation', California Municipal Revenue \&Tax Association (CMRTA) Meeting, Pinole, CA, August 15. [Online], [Retrieved October 28, 2020], https://www.sjsu.edu/people/annette. nellen/website/TaxReform/ECommerceTax8-15-08.pdf.

- Papis-Almansa, M. (2019), 'VAT and electronic commerce: the new rules as a means for simplification, combatting fraud and creating a more level playing field?'. (ERA Forum) 20:201-223, 221.

- Redih, E. (2020), 'E-commerce market: what it was like in 2019 and what it will be like in 2020', Business Censor, 14 January. [Online], [Retrieved October 
05 ,

2020],https://biz.censor.net.ua/resona nce/3169606/rynok_elektronnoyi_kom mertsii_kakim_on_byl_v_2019_i_kakim_ budet_v_2020.

- The Organization for Economic Cooperation and Development.[Online], [Retrieved October 01, 2020], https://www.oecd.org.

- Tymchenko, L. MELNYK, P., TARANGUL, L. and others (2008), Legal regulation of e-commerce, Tymchenko L. (ed), National University of State Tax Service of Ukraine, Irpin.
- Verkhovna Rada of Ukraine (2020), 'On Amendments to the Tax Code of Ukraine and Other Laws of Ukraine Concerning Support of Taxpayers for the Period of Measures Aimed at Preventing the Occurrence and Spread of Coronavirus Disease (COVID-19)', Law of Ukraine of March 17, 2020 № 533-IX. [Online], [Retrieved October 12, 2020], https://zakon.rada.gov.ua.

- Yurchuk, G. (2000), 'E-commerce and its prospects for the banking system', Part 1: E-commerce as part of the world economy, Bulletin of the National Bank of Ukraine, 9, 20-25. 